\title{
Recent Trends in Transit Migration Routes Through Turkey to Europe
}

\author{
Erhan AYGÜN ${ }^{1 \oplus}$
}

Due to its geographical proximity to Western countries, Turkey is becoming one of the critical points of a complex migration system that includes asylum seekers, refugees, regular, irregular and transit migrants. For this reason, Turkey, regarded as a "transition country", is a very important station on the way to European destinations. With this aspect, Turkey has become a key country in terms of the EU's border security, and this feature has become the focal point of EU-Turkey relations.

Despite the importance and insufficient opportunities for irregular migration to the EU, Turkey's struggle with transit migration will be discussed in this study. Furthermore, the routes used by refugees to reach Europe through Turkey, as well as the statistics related with these routes, will be examined.

Keywords: transit migration, Turkey, the EU, migration routes, immigrants

\section{Introduction}

Due to globalisation, increasing inequalities in living standards and acceleration of communication, the fact that different parts of the world become more aware of each other has turned the direction of millions of African and Asian people in search of a new life to the north and west. The target shown in both directions is Europe. The rich European countries, which are the target of long-distance migration movements originating from the "problematic" regions of the world, try to protect their borders with the new regulations they put into effect for the "unwanted" who want to enter. ${ }^{2}$ Hence, those who wish to migrate turn to illegal ways more frequently in order to reach the destination countries that have become more difficult to "reach". Consequently, irregular and transit migration activities are the most common routes used to reach Europe today.

Transit migration is generally considered a subcategory of irregular migration and does not have a universally accepted definition. According to the United Nations, transit migration is 'the type of migration that immigrants use temporarily to cross

PhD student, University of Public Service; e-mail: erhanaygun93@hotmail.com

Myron Weiner, 'Ethics, National Sovereignty and the Control of Immigration', International Migration Review 30, no 1 (1996). 
their country of transition to the destination country'. ${ }^{3}$ On the other hand, a transit country is 'the country that is geographically located between the source and destination countries and has to manage the temporary population that is likely to turn into a legal or illegal resident population at any time'. ${ }^{4}$ The International Organization for Migration defines the transit country as 'the country through which legal or illegal immigration flows pass'. ${ }^{5}$

The term transit migration refers to certain forms of migration that are apparently temporary. This includes migrants who move from one country to another because they had their actual purpose or because changing circumstances, increasing pressures or new objectives dictate so. More generally, the term also refers to "long journeys full of difficulties”. Usually, these journeys are longer in distance and time, constantly changing direction, and can sometimes be dangerous. Transit migration is used as an "umbrella term". It can cover many different categories, such as refugees and labour migrants. But it is often used for mixed migration flows such as regular and/or irregular migration and temporary migration. The concept of transit migration is a politicised concept that is used for unwanted immigration to developed EU countries, and transit countries are also held responsible for this unwanted immigration. ${ }^{6}$

Discourses on transit migration are exaggerated, they have a warning purpose pointing to waves of migrants heading north and west, the masses and millions of immigrants. With the impact of the September 11 events, this concept has been used in association with terrorism since 2001 and is considered a threat to all kinds of security of target countries, especially border security. ${ }^{7}$

\section{Countries of origin located around Turkey's hinterland}

Turkey is highly vulnerable to irregular migration movements stemming from unstable areas. There are two main reasons for this: its geographical location in relation to the Asian, European and African continents, as well as its natural bridge feature between the politically and economically underdeveloped some Middle East, Caucasus and Central Asian states and the wealthy European countries. Furthermore, Turkey's positive separation from neighbouring countries as a result of its recent economic development has added the adjective "target country" to the "transit country". Along with these, Turkey has been the target of mass migration flows to Anatolia as a result of the turmoil in the Middle East, the Caucasus and the Western Balkans, where it has historical, religious and cultural ties. Thus, Turkey has transitioned from a "migrant country" to an "immigrant country", a process that began with the export of labour

UNECE, Defining and Measuring Circular Migration (United Nations Economic Commission for Europe, 2016).

4 Marcel Bazin and Stéphane de Tapia, Türkiye coğrafyası: la Turquie : géographie d’une puissance émergente (İstanbul: Iletisim, 2015).

5 IOM, Glossary on Migration, 2019.

6 Franck Düvell, ‘Clandestine Migration in Europe’, Social Science Information 47, no 4 (2008), 479-497. Ibid. 497. 
to Western Europe in the 1960s. The fact that the problems in Turkey's unstable hinterland continue to worsen indicates that this standard will be maintained in the near future.

Immigrants from countries such as Syria, Iraq, Afghanistan, Bangladesh, Pakistan, Palestine, Ethiopia, Sudan and Somalia, which are sources of international migration, pass through Turkey in some way. While evaluating Turkey as a target country, a significant portion of them see our country as a transit country. For the immigrants in the second group, Turkey is a transit country to reach the destination country.

According to UN data, the fact that refugees in Turkey, Jordan, Palestine, Lebanon and Pakistan, which are the countries hosting the highest number of refugees in the world, correspond to a high rate in the population of the countries they live in, increases the likelihood of them turning to third countries because it causes problems in meeting their needs. Therefore, the priority target for refugees clustered in these countries is developed European countries. For this reason, Turkey draws attention with its high refugee population as well as being on the transit route of migration movements towards Europe.

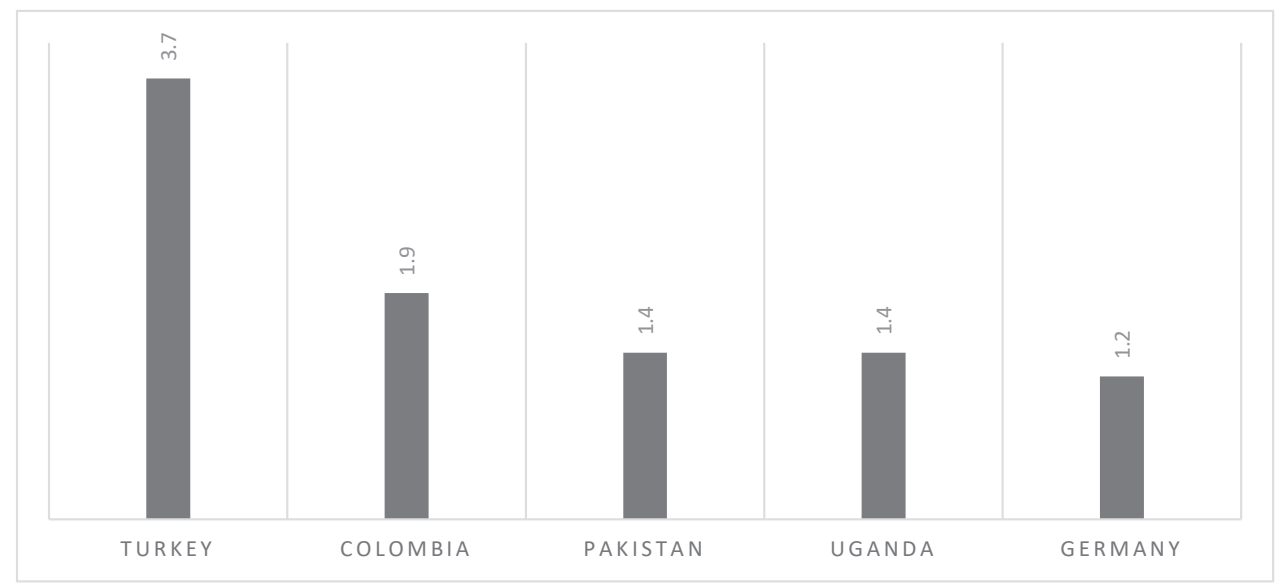

Figure 1: The first 5 countries with the highest number of refugees (in million) (as of end-2020)

Source: Compiled by the author based on UNHCR 2021 data.

According to the data showed above, the most important refugee hosts worldwide are Turkey, Colombia, Pakistan, Uganda and Germany. The fact that refugees correspond to a high proportion of the population of these countries they live in increases the possibility of turning to third countries as it causes problems in meeting their needs. The priority targets for the refugees concentrated in these countries are the developed European countries. For this reason, Turkey draws attention with its high refugee population as well as being on the transit route of migration movements towards Europe. 
Since the 1990s, Turkey has been in a critical position for immigrants who have fled from conflicts and wars and headed to Europe with the hope of a comfortable life to achieve their goals. As it is shown in the map below, immigrants departing from Central and Southeast Asian countries such as Afghanistan, Pakistan, Bangladesh, Middle East countries such as Syria, Iraq and Palestine, as well as African countries such as South Sudan, Somalia and Eritrea, consider Turkey a transit country on their way to Europe. 57\% of the world's refugees originate from South Sudan, Afghanistan and Syria and considering the nationalities of illegal immigrants caught at EU borders, Tunisia, Afghanistan, Pakistan, Albania, Algeria, Morocco, Eritrea, Somalia and Bangladesh are in the first place, illustrates the importance of Turkey in the context of transit migration. ${ }^{8}$

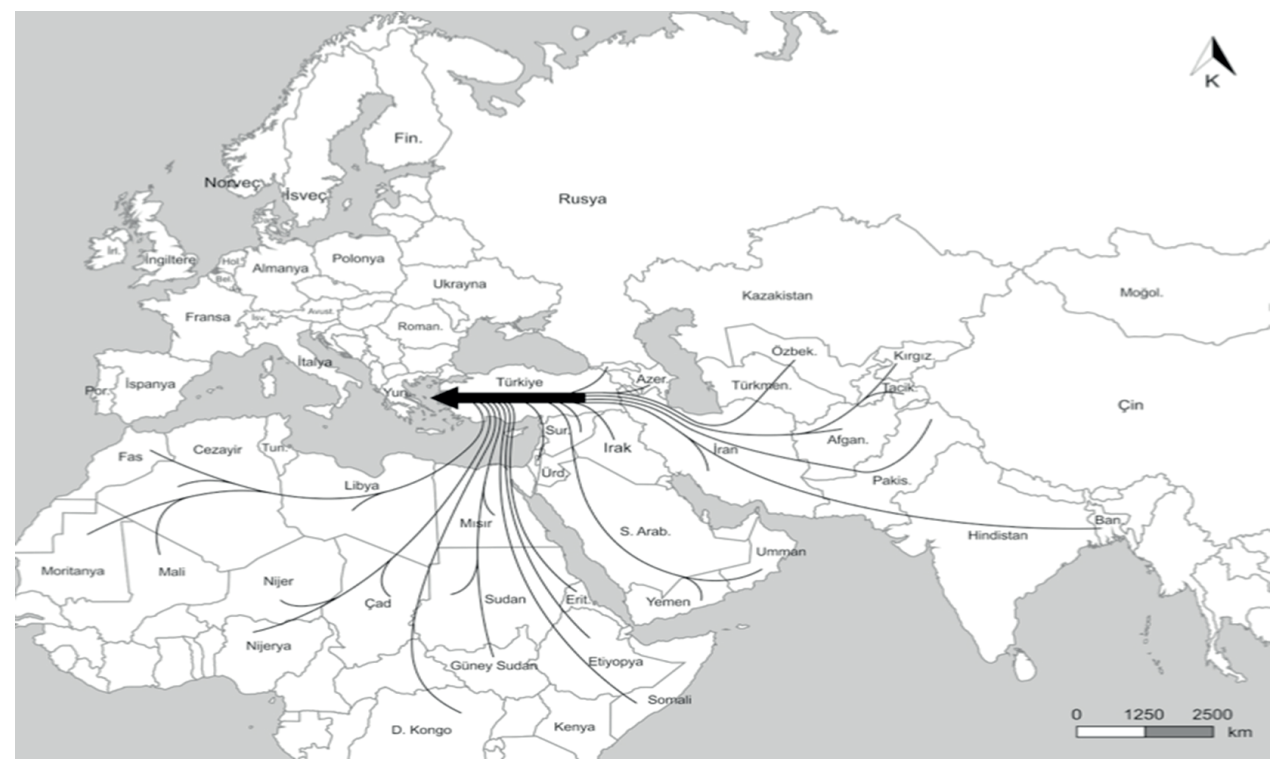

Map 1: Migration movements via Turkey (transit) towards Europe

Source: Compiled by the author based on UN Data.

In addition, the fact that they will continue to cause more irregular migrants due to the continuing instability, conflict and problems in these countries is an indication that the critical position of Turkey on transit migration will not remain short-term.

$8 \quad$ UNHCR, Global Trends. Forced Displacement in 2018. 


\section{Migration routes between Turkey and Europe: The route of the Eastern Mediterranean and Western Balkans}

Geographically, the African continent and the Middle East are the EU's closest neighbours and familiar sources of irregular migration to the European continent. Almost $90 \%$ of illegal border crossings to the EU happens through the Mediterranean. ${ }^{9}$ In order to reach Europe, immigrants prefer the West African Route, the Western Mediterranean Route, the Central Mediterranean Route, the Eastern Mediterranean Route, the Western Balkan Route, the Black Sea Route, the Eastern Border and the Greece and Albania Circular Routes. However, the Eastern Mediterranean and Western Balkan Routes are the two most important routes used by migrants to reach EU countries.

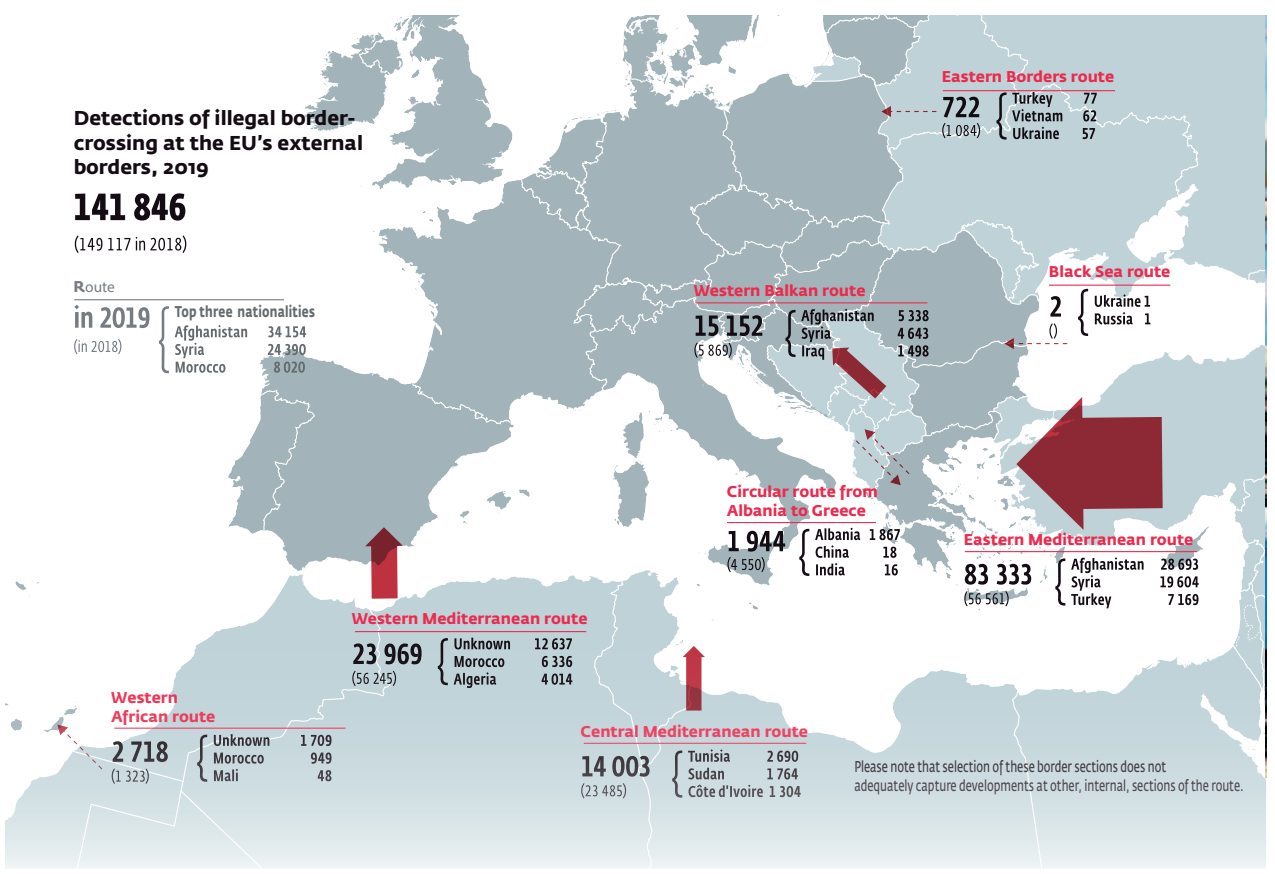

Map 2: Detections of illegal border-crossing at the EU's external borders

Source: Frontex Annual Risk Analysis 2020.

Especially the Eastern Mediterranean Route has been used as an entry route to Europe for many years. According to the map above, the number of illegal immigrants arriving in Europe in 2019 was 141,846. Considering the generality of illegal crossings, it is understood that $69 \%(98,485$ people) took place via the Eastern Mediterranean and

Jean-Dominique Giuliani, 'The Challenge of Illegal Immigration in the Mediterranean', European Issues no 352 (2015). 
Western Balkan routes. Despite the measures taken to prevent illegal border crossings and agreements between countries, the interest of immigrants in this route continues.

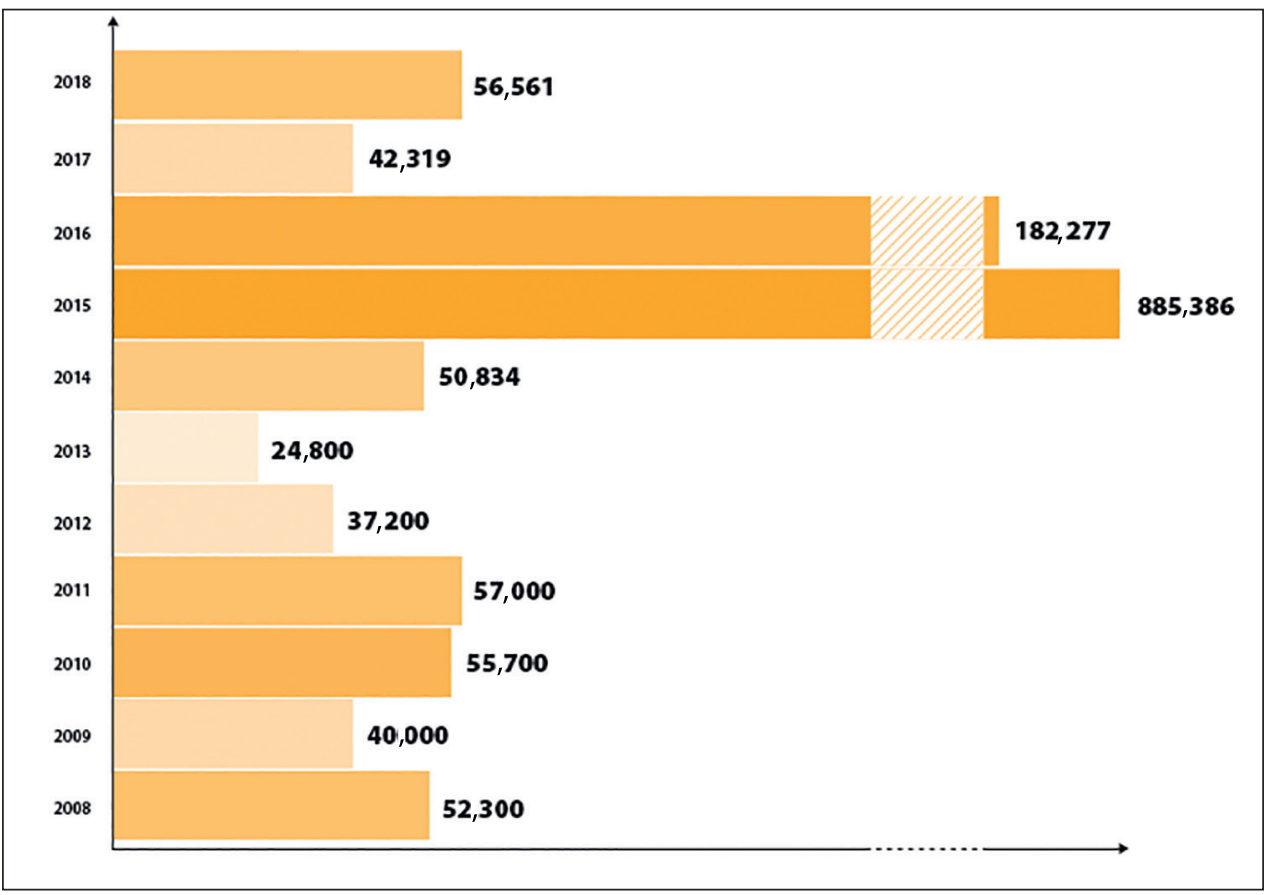

Figure 2: Illegal border crossings on the Eastern Mediterranean route in numbers

Source: Frontex, Eastern Mediterranean Route, 2019.

Between 2008 and 2018, 1,484,377 illegal immigrants crossed the Eastern Mediterranean route to reach Europe. Furthermore, in 2015 alone, 885,000 immigrants used this route. This is the largest migration wave that Europe has faced since World War II. Therefore, it is frequently emphasised that the Eastern Mediterranean Route is an important place for immigrants.

The position of Turkey on this route is also reflected in international organisation reports. Indeed, the results of the International Organization for Migration's fieldwork with illegal immigrants using the Eastern Mediterranean Route in 2017 show that it takes a year or more for immigrants to travel to the destination country. Turkey and Iran are the most frequently used countries for accommodation (transit migration bases) in this process. ${ }^{10}$

10 IOM, New UN Migration Report Shows Complex Evolution of Pathways, Cost of Eastern Mediterranean Route, 2017. 


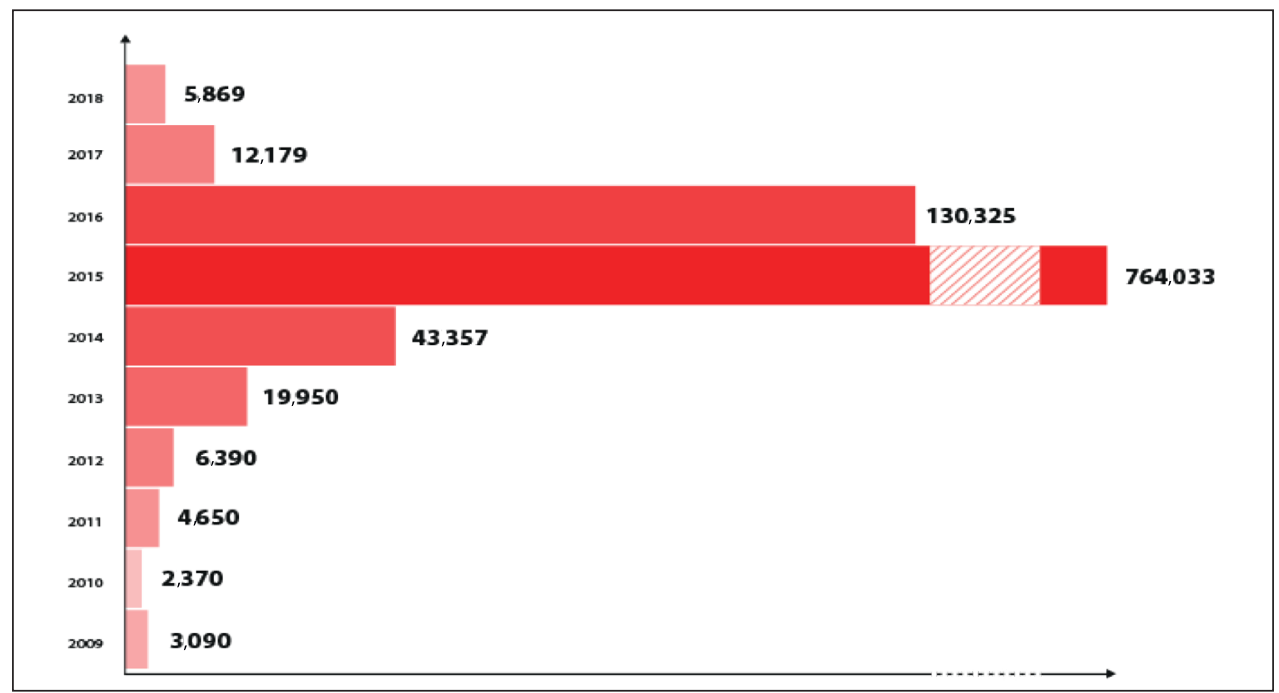

Figure 3: Illegal border crossings on the Western Balkan Route in numbers

Source: Frontex, Western Balkan Route, 2019.

The Western Balkan Route is also frequently used by immigrants to reach Europe. Turkey is the main source of this route on the land border between East and West. Immigrants using this route stay in one or more countries upon their arrival in the destination country. Especially Istanbul has the feature of being the most frequently used point as a transit base on this route. ${ }^{11}$ This route has become the main route for refugees and immigrants crossing the Greek-North Macedonian border from Turkey to Greece and from the north to the Western Balkans in 2015, a total of 992,213 immigrants used this route between 2009-2018. Moreover, the number of immigrants using this route is 764,033 in 2015 alone. $^{12}$

\section{Recent developments in the routes: Decreased or increased?}

As in previous years, irregular migration and asylum have continued to dominate the European migration debate in 2020. The debate was centred on whether the mobility restrictions and economic slowdown connected to Covid-19 would result in a shift in trends. As a result, the observed overall decline had no effect on the main roads in the same way. In 2020, the Eastern Mediterranean Route will be replaced by the

Ibid.

12 Katie Kuschminder, Talitha Dubow, Ahmet İçduygu, Aysen Üstübici, Eda Kirişçioğlu, Godfried Engbersen, and Olga Mitrovic, Decision Making on the Balkan Route and the EU-Turkey Statement (UNU-MERIT, 2019). 
Central Mediterranean and Western Balkan Routes. The number of detections along the Eastern Mediterranean Route fell by 75.0\% from 75,280 in 2019 to 18,490 in 2020.

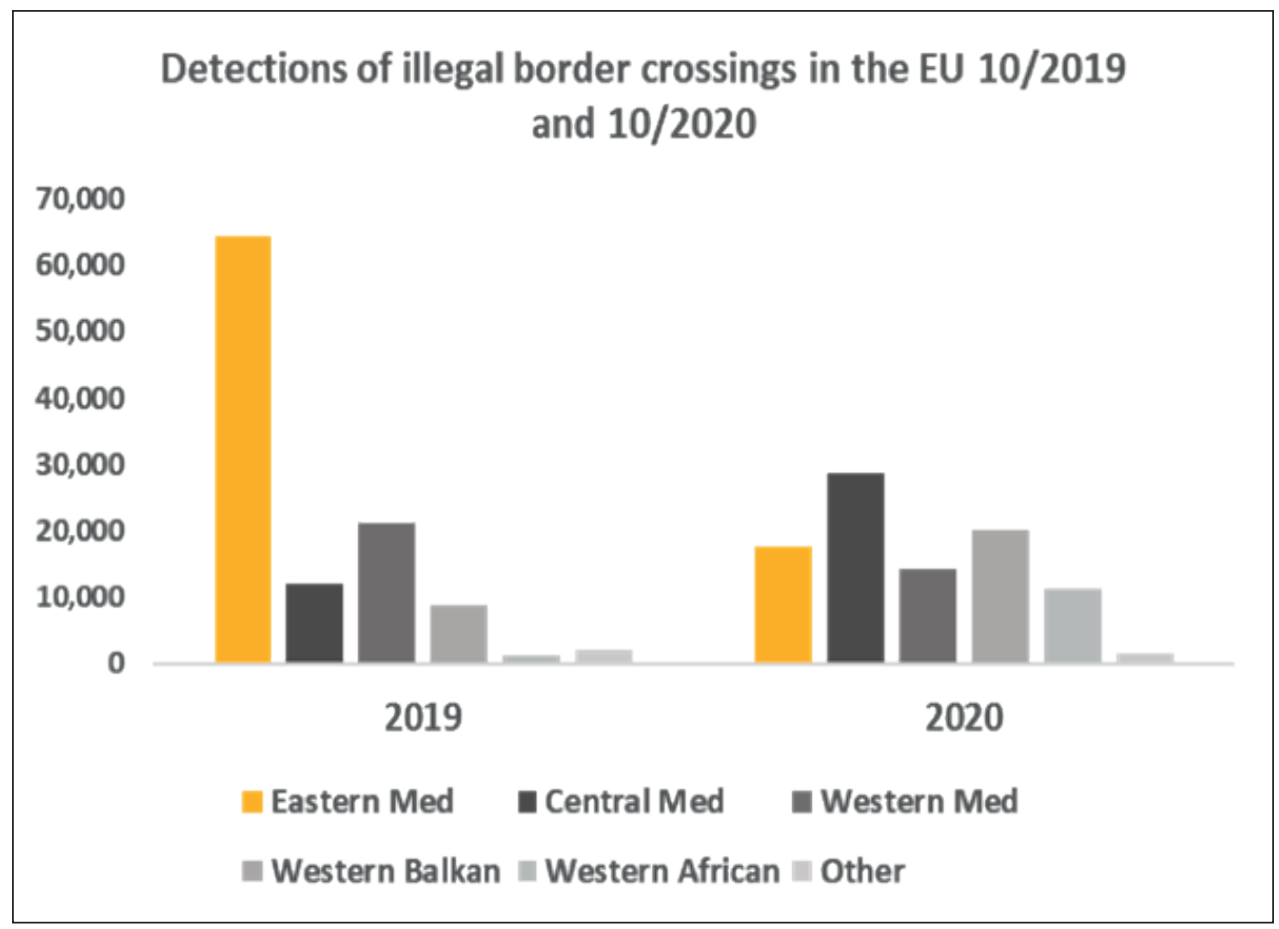

Figure 4: Detections of illegal border crossings 2019-2020

Source: Frontex Annual Risk Analysis 2021.

This shift was primarily influenced by events on the Greece-Turkey border in early 2020. For the first time since the EU-Turkey migration agreement was signed in 2016, a significant flow of refugees from Turkey began to move towards Greece. Greece reacted by closing its borders and suspending the acceptance of asylum seekers. As a result, arrivals on the Greek islands decreased significantly. According to UNHCR data, the total number of arrivals fell from around 60,000 in 2019 to around 9,300 in the first ten months of 2020. Even so, the Greek asylum and reception system is still under enormous strain. According to the UNHCR, approximately 120,000 refugees and migrants are currently residing on Greek territory.

In 2020, the Western Balkans remained a transit route for mixed flows of migrants en route to final destinations in EU countries. The region's registered migrants and refugees have increased significantly in recent years and have remained high despite Covid-19 preventative measures. 


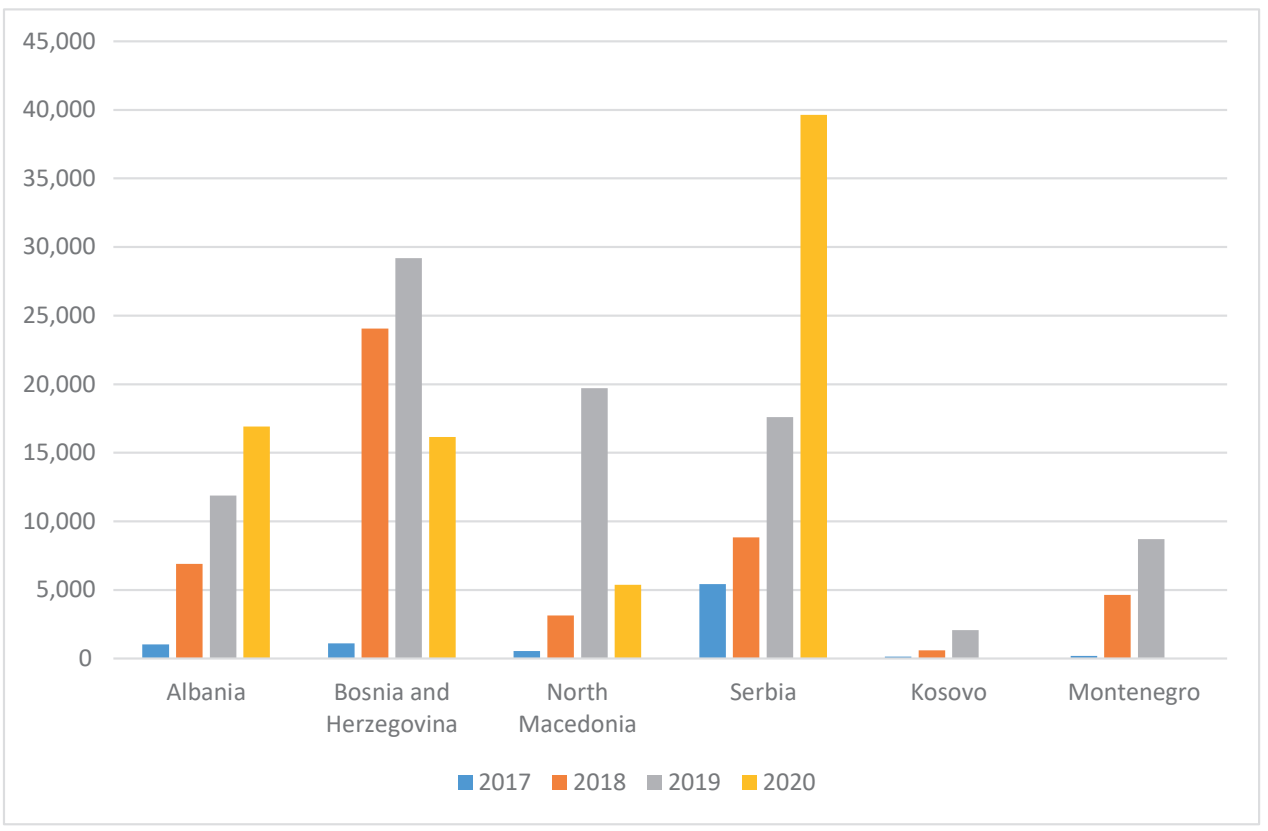

Figure 5: Registered migrant and refugee arrivals in the Western Balkans 2017-2020

Source: IOM, Flow monitoring, Europe, 2020.

Each Western Balkan country experienced a significant increase in the number of newly registered migrants and refugees, especially in 2019 compared to 2018. Even in 2020, the number of registered migrants and refugees was also quite high, with Serbia receiving approximately 40,000 new arrivals. Other countries reported a decrease in numbers compared to 2019, most likely as a result of Covid-19-related measures and changing migration routes in the Western Balkans. When the number of arrivals recorded by IOM is compared, the trend decreases in the second quarter of 2020 and then increases again in the following period.

\section{Conclusion}

Considering the routes that are heavily used through Turkey, the mobility of migrants on the Eastern Mediterranean Route continues, with an average of 165 migrants using this route per day (in 2019). The General Directorate of Migration Management's density map and the United Nations' migration map confirm the intensity and quality of this mobility, with overlapping results. Compared with other statistical data, both maps suggest that Turkey will continue to maintain its position as a transit migration base. 
In case of transit migration, not having legal status limits immigrants' access to legal, economic and social opportunities makes them vulnerable to discrimination, racism and violence, and creates barriers to labour market access. During the transit migration process, they face physical and environmental risks such as disease, hunger and trauma. During the migration process, which they began healthily, they become physically weakened due to the adverse conditions they encountered, and they also face mental health issues. They are frequently refused employment, are unable to rent a home, and do not have access to basic services such as education and health care in the countries where they are transiting.

\section{References}

Bazin, Marcel and Stéphane de Tapia, Türkiye coğrafyası: la Turquie : géographie d'une puissance émergente. İstanbul: Iletisim, 2015.

Düvell, Franck, 'Clandestine Migration in Europe'. Social Science Information 47, no 4 (2008), 479-497. Online: https://doi.org/10.1177/0539018408096442

Frontex, Western Balkan Route, 2019. Online: https://frontex.europa.eu/we-know/ migratory-routes/western-balkan-route/

Frontex, Eastern Mediterranean Route, 2019. Online: https://frontex.europa.eu/we-know/ migratory-routes/eastern-mediterranean-route/

Frontex Annual Risk Analysis 2020. Online: https://frontex.europa.eu/publications/frontexreleases-risk-analysis-for-2020-vp0TZ7

Frontex Annual Risk Analysis 2021. Online: https://frontex.europa.eu/publications/frontexreleases-risk-analysis-for-2021-MmzGl0

Giuliani, Jean-Dominique, ‘The Challenge of Illegal Immigration in the Mediterranean’. European Issues no 352 (2015). Online: www.robert-schuman.eu/en/europeanissues/0352-the-challenge-of-illegal-immigration-in-the-mediterranean

IOM, New UN Migration Report Shows Complex Evolution of Pathways, Cost of Eastern Mediterranean Route, 2017. Online: www.iom.int/news/new-un-migration-reportshows-complex-evolution-pathways-cost-eastern-mediterranean-route

IOM, Glossary on Migration, 2019. Online: www.iom.int/glossary-migration-2019

IOM, Flow monitoring, Europe, 2020. Online: https://migration.iom.int/ europe?type $=$ arrivals

Kuschminder, Katie, Talitha Dubow, Ahmet İçduygu, Aysen Üstübici, Eda Kirişçioğlu, Godfried Engbersen and Olga Mitrovic, Decision Making on the Balkan Route and the EU-Turkey Statement. UNU-MERIT, 2019.

UNECE, Defining and Measuring Circular Migration. United Nations Economic Commission for Europe, 2016.

UNHCR, Global Trends. Forced Displacement in 2018. Online: www.unhcr.org/statistics/ unhcrstats/5d08d7ee7/unhcr-global-trends-2018.html

UNHCR, Refugee Statistics, 2021. UNHCR's Refugee Population Statistics Database. Online: www.unhcr.org/refugee-statistics/ 
Erhan AYGÜN: Recent Trends in Transit Migration Routes Through Turkey to Europe

Weiner, Myron, 'Ethics, National Sovereignty and the Control of Immigration'.

International Migration Review 30, no 1 (1996), 171-197. Online: https://doi. org/10.2307/2547466 